Kanneboyena, O., S. Suthari, A. Ragan and Vatsavaya S. Raju 2015.Conservation priorities of NTFP species in dry decidious forests of Adilabad District, Telangana, India. Our Nature 13(1): 1-7. DOI: http://dx.doi.org/10.3126/on.v13i1. 14202

\title{
Conservation Priorities of NTFP Species in Dry Deciduous Forests of Adilabad District, Telangana, India
}

\author{
Omkar Kanneboyena ${ }^{1}$, Sateesh Suthari ${ }^{2 *}$, A. Ragan $^{3}$ and Vatsavaya S. Raju ${ }^{3}$ \\ ${ }^{1}$ PSC and KVSC Government College, Nandyal, Kurnool, Andhra Pradesh- 518 502, India \\ ${ }^{2}$ Dept. of Plant Sciences, School of Life Sciences, University of Hyderabad, Central University P.O., Hyderabad, \\ Telangana-500 046, India \\ ${ }^{3}$ Plant Systematics Laboratory, Dept. of Botany, Kakatiya University, Warangal, Telangana- 506009 , India \\ *E-mail: suthari.botany@gmail.com
}

Received: 2015.01.30, Accepted: 2015.06.13

\begin{abstract}
Non-Timber Forest Products (NTFPs) have been used by ethnic and non-ethnic people for their food, shelter, medicine and commerce in Adilabad district of Northern Telangana. Over exploitation of the products has reduced the economic plant taxa and led to the loss of plant species which are essential for ecosystem diversity. The availability and distribution of the 16 NTFP species studied are not uniform in the district as per the phytosociological study. They are prioritized into three categories on the basis of score attained in the devised scale. Among these, Firmiana simplex, Givotia mulaccana, and Aegle marmelos shall receive the highest conservation priority, followed by Madhuca longifolia var. latifolia, Dendrocalamus strictus at moderate level while Terminalia bellerica, Syzygium cumini and Tamarindus indica are of low category which do not require much conservation attempt.
\end{abstract}

Key words: Non-Timber Forest Products, dry deciduous forest, conservation priority, Adilabad.

\section{Introduction}

People live near the forest depend on the forest for their survival. Tribal and nontribal communities living inside and on the fringes of forest areas depend on NTFP species for their food, shelter, medicine and commerce. Non-Timber Forest Products (NTFPs) have been utilizing by the ethnic and non-ethnic people for their economic and healthcare measures. The significance of NTFPs to the State was perhaps realized first when the report of the Industrial Survey Committee appointed by the erstwhile Government of Central Provinces and Berar was published in 1939. As a consequence of this realization, trade in some NTFPs was nationalized. It is estimated that 275 million
(27\%) poor rural people in India depend on NTFPs for at least part of their subsistence and cash livelihoods (Bhattacharya and Hayat, 2004; Malhotra and Bhattacharya, 2010). This dependency is particularly intense for half of India's 89 million tribal people, the most disadvantaged section of the society.

Only in late 80 's, there were some attempts made and highlighted the need to manage and study of the non-timber forest products. In general, tribal economy entirely depends on the health of forest and volume of the forest produce. The forest policies contain a specific provision for the integration of tribal interests with forests. 
NTFPs valuing is increasing and estimated that currently, some US\$90 billion worth of NTFPs are reportedly extracted worldwide annually and about one third of the same is consumed in the local economy without it in the market (Pimental et al., 1997). In India, a significant contribution of revenue comes from NTFPs, and $70-80 \%$ of forest exports are only NTFPs (Sinha and Bawa, 2002).

Studies conducted in some Indian states have shown that contribution of NTFPs to the total income of the households varied between 10 to $70 \%$ and majority of the forest dwellers depend on forests for 25 to $50 \%$ of their food requirements.

\section{Study Area}

Adilabad district lies in between latitudes $18^{\circ} 40^{\prime}$ and $19^{\circ} 56^{\prime} \mathrm{N}$ and longitudes $77^{\circ} 47^{\prime}$ and $80^{\circ} 00^{\prime} \mathrm{E}$. It is bounded by Yeotmal and Chanda districts on the north, Chanda district in the east, Nanded district of Maharashtra in the west and Karimnagar and Nizamabad districts of Telangana in the south. The ethnic population constitutes $17.08 \%$ of the total population of the district, with prominent indigenous tribal groups such as Gonds, Koyas, Pardhans (Pradhans), Naikpods, Mannewars, Kolams (Kolavars), Andhs, Thotis, Bhils, Khatis, Wojaris, Yerukalas and Lambadis (Anonymous, 2011). Of these, Gonds stand for the dominant group (52.16\%). Geographically, these people are responsible for the name Gondwanaland, the southern of the two super continents believed to have constituted super continent 'the Pangea'. The study site enjoys typical tropical climate with four seasons, with an average rainfall of $742 \mathrm{~mm}$ and temperature varying from $28-41^{\circ} \mathrm{C}$ in the hot season (Anonymous, 1975). In winter season, the temperature comes down to about $4^{\circ} \mathrm{C}$ in Jannaram
Division of the district (Suthari, 2013). The district occupies the second position with an area of $7066.47 \mathrm{sq} \mathrm{km}$ in the state in regard to the area under forest cover in Telangana state (Anonymous, 2013). It is one of the backward districts and occupies $30.36 \%$ of tropical dry deciduous forest cover (Fig. 1).

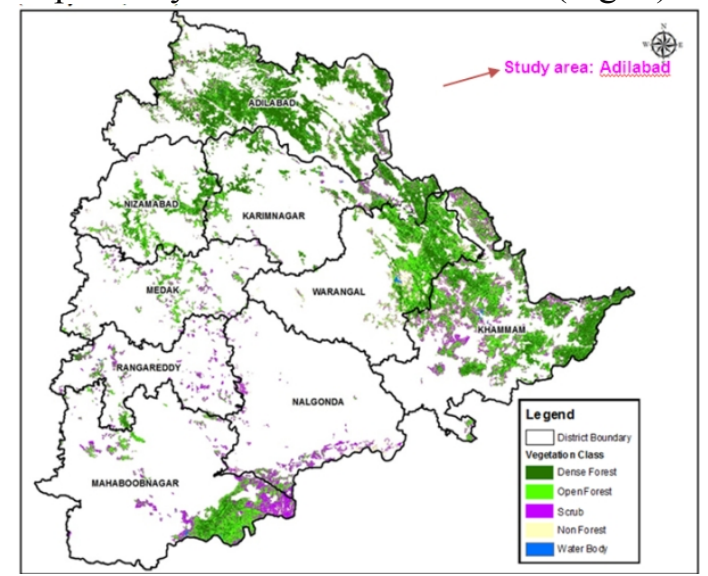

Figure 1. Forest cover map of Telangana and study area.

Telangana has 23,272.04 sq km of area under forest cover (very dense 616.41, moderate dense 9474.71, open forest $8659.76 \mathrm{sq} \mathrm{km}$ (excl. scrub 4521.16 and non-forest $2590.70 \mathrm{sq} \mathrm{km}$ ) (Anonymous, 2013).

\section{Materials and methods NTFPs and Household survey}

During the field exploration studies, the primary data about NTFP's was gathered from the ethnic and non-ethnic people of Adilabad district whether it is used for the purpose of self-use and/or commercial along with the seasonal availability (month / months and whole year). The months of January to May are considered as the peak season for NTFPs collection. The other important season was monsoon (JuneSeptember). So, the NTFPs collection was optimum during summer and monsoon 
seasons. The collected NTFPs samples were deposited at Museum, Department of Botany, Kakatiya University and the processed plant voucher specimens were housed at Kakatiya University Herbarium, Warangal (KUW).

\section{NTFP availability and dependence}

The NTFPs are used as food, fodder, medicine, household articles, fencing and non-commercial as well as commercial purposes, as revealed from household survey. Totally 183 plant taxa were identified for general use category, most of these are available in quantities. The products from them are of high commercial value. The level of dependence on NTFPs was based on the availability of other resources. Where the availability of resources is high, there was less dependence on NTFPs. The poor people and forest fringe villagers mostly depend on the collection of NTFPs. The contribution of NTFPs to annual household income varies. Accordingly, the households are categorized into three categories: (i) High dependent where NTFPs contributed more than $50 \%$ in annual household income; (ii) Moderately dependent - with 20-50\% contribution; and (iii) Low dependent - with $<20 \%$ contribution. The high dependence on NTFPs was observed in all the areas of the district. The major NTFPs are bamboo, tendu leaves, gum karaya, whereas the remaining provide moderate to low contribution of their income (Omkar, 2010).

\section{Scale of Scoring and Conservation Prioritization}

Twelve criteria with different values were assigned to scores (three to zero) based on, viz. distribution pattern, occurrence and harvesting, as per the Scale devised by
Silori et al. (2005), with a slight modification. When the NTFP species is present in less than $40 \%$ of the sampled area (plots), the scale awards a score of three (3); when it is between 40-60, it accords one (1). Otherwise, it is not for conservation earning and no credits for care. If the NTFP species is in a regeneration stage, it is to be assigned the score of three; score two when trees are also found with saplings, and score one when there are establishments and regeneration only. There is no score for a NTFP taxon with all the above stages. The score is based on the harvested parts. When the roots are harvested, the NTFP species shall be given score of three, two when collected for sale and when aerial parts are collected other than leaves, the score will be one for a species whose produce is gathered for self- consumption as flowers, fruits and seeds (Tab. 1).

\section{Results and discussion}

NTFP species Priority list for Conservation Based on the scale of scoring adopted the NTFP species of Adilabad district are screened to prepare the priority list for conservation (Tab. 2). In the descending order of the score the species attained (20 to 4), they occupy the ladder of conservation priority. The NTFP taxa assessed were obviously the tree species indigenous to tropical deciduous forest. The plant taxa are grouped into three categories on the basis of priority they must receive as high to low.

(i) High Priority: There are four NTFP species which are very important for the region. They are Firmiana simplex (tapsi for gum) with the score 20, Givotia moluccana (poniki used for Nirmal toy making) and Aegle marmelos (maredu for medicinal) species with the score 16, Phyllanthus emblica (usiri for fruits) with the score 15 
Omkar Kanneboyena, Sateesh Suthari, A. Ragan and Vatsavaya S. Raju / Our Nature (2015), 13(1): 1-7.

Table 1. Parameters and Scoring for prioritization of NTFP species.

\begin{tabular}{ll}
\hline Parameter & Score \\
\hline Distribution & 3 \\
1. NTFP species in a sampled plot: $<40 \%$ & 1 \\
2. NTFP species in a sampled plot: $>40 \%$ and $<60 \%$ & 0 \\
3. NTFP species in a sampled plot: $>60 \%$ & 3 \\
\hline Occurrence & 2 \\
1. NTFP species recorded only in regeneration stage & 1 \\
2. NTFP species recorded in regeneration and sampling stage & 0 \\
3. NTFP species recorded in regeneration, establishment, tree form & \\
4. NTFP species recorded no score in all above three stages & 3 \\
\hline Parts Harvested & 2 \\
1. Roots & 1 \\
2. Aerial parts - Stem/Bark or Gum (other than leaves) & 1 \\
3. Flowers, fruits and seeds & 2 \\
\hline Utilization & \\
1. Collection for self-consumption & \\
2. Collection for commercial sale &
\end{tabular}

(after Silori et al., 2005, present study)

Table 2. NTFP species and distributional status, mode of collection, conservation priority of the study area.

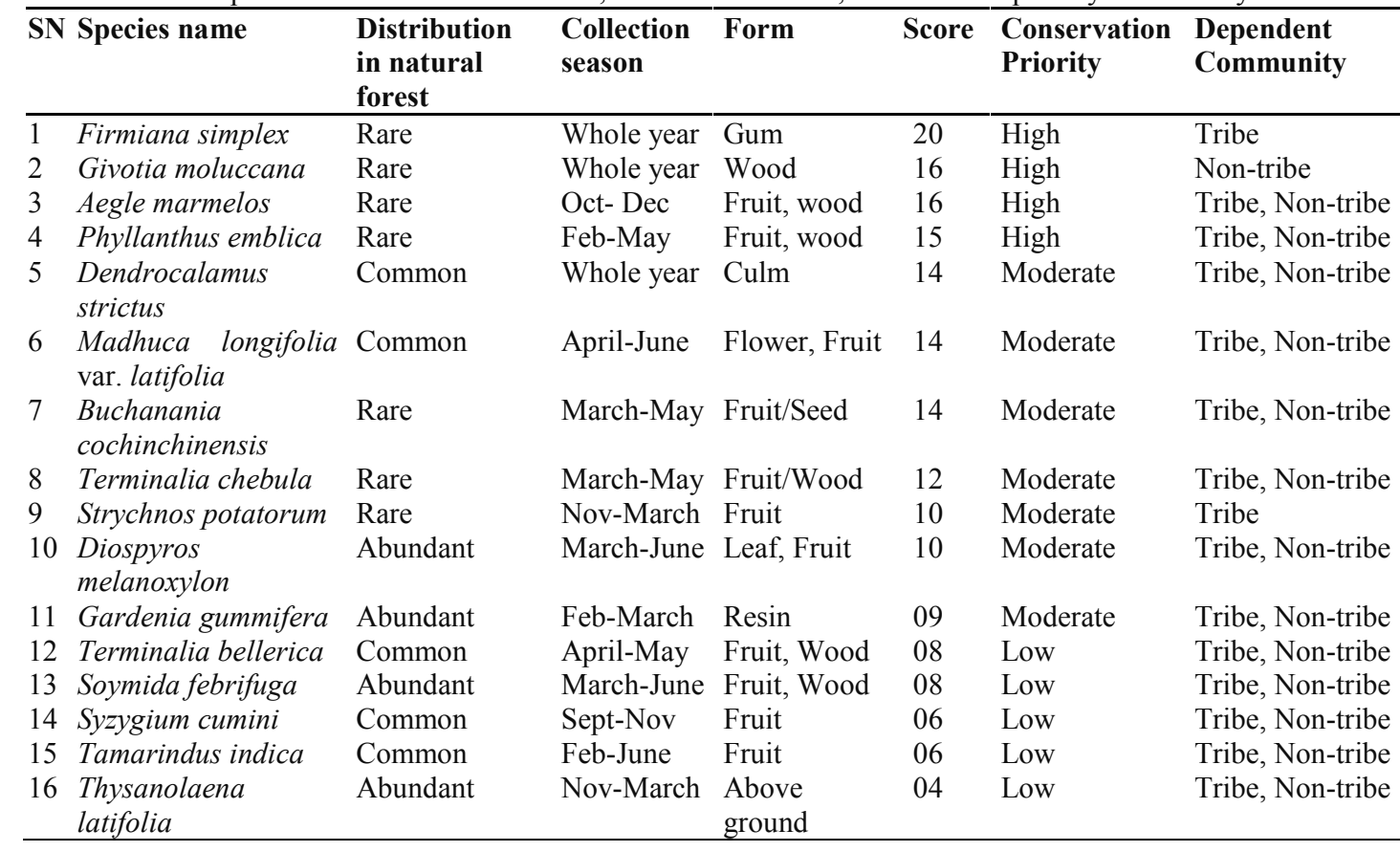




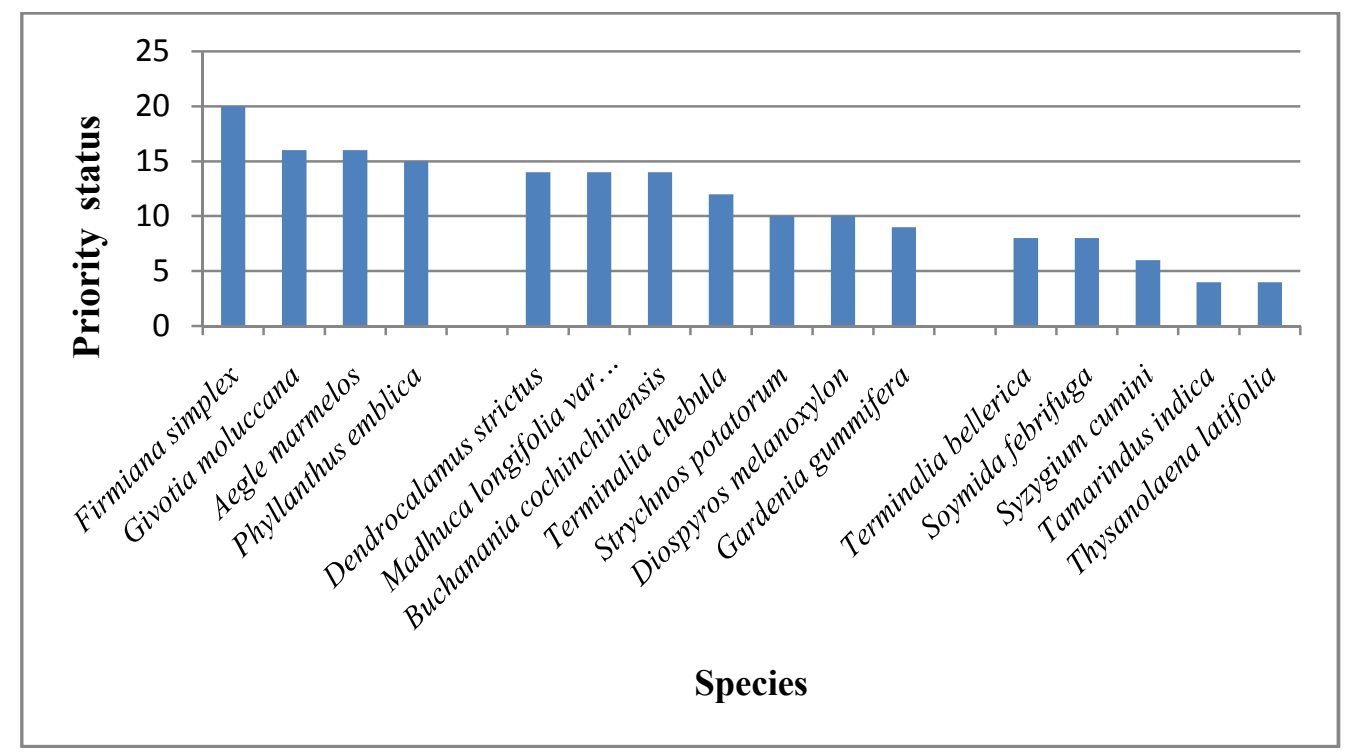

Figure 2. NTFP species priority status and conservation priority.

closely fallows them. In the priority list of Silori et al. (2005), Phyllanthus emblica was topped the list followed by Strychnos potatorum, Firmiana simplex and Sygyzium cumini (Fig. 2).

(ii) Moderate Priority: There are seven taxa which fall under this category. With the score 14, Buchanania cochinchinensis (pedda morli- seed), Dendrocalamus strictus (bamboo) and Madhuca longifolia var. latifolia (ippa- seed, fresh corolla) shall receive the same attention. Terminalia chebula (karakkaya- fruit) with 12 and Diospyros melanoxylon (tuniki- leaf, fruit, wood) with the score of nine. As per the assessment of Silori et al. (2005), Dendrocalamus strictus, Gardenia gummifera and Terminalia chebula occupy the same status. However, the present study justify Aegle marmelos to High Priority while Soymida febrifuga goes down to Low Priority (Fig. 2). (iii) Low Priority: There are six plant species fall under this category Terminalia bellerica (tani - fruits) and Soymida febrifuga (somi - timber, fruit) attained the score eight, Syzygium cumini (neredu fruits) six, and Tamarindus indica (chinta fruits), Thysanolaena latifolia (konda cheepuru - broom) and Ziziphus xylopyrus (gotte - fruits edible; leaves fodder to sheep and goats) with four. Anogeissus latifolia (tiruman - wood) was not assessed in the present study though it was in the list of Silori et al. (2005). Instead, the broom grass considered for economic significance in terms of harvest and income to the local people (Fig. 2).

\section{Conservational Needs}

The above assessment seems to be is realistic and perhaps truly reflects their ecological status and dynamics in dry deciduous forests of Adilabad district. The present study brings to focus the level of 
Omkar Kanneboyena, Sateesh Suthari, A. Ragan and Vatsavaya S. Raju / Our Nature (2015), 13(1): 1-7.

attention to be paid to these plant species in the Forest Working Plans and in the workouts of VSS or Community Forestry people. It ultimately helps the Girijan Cooperative Corporation (GCC) and other selfhelp groups revitalize their inflows. There is immediate need to conserve the NTFP species for the sustainability and empowerment of tribes and non-tribes of the district (Omkar et al., 2008).

Conflict between forest products and forest conservation arises everywhere, but the studies have revealed both the conservation and socio-economic aspect are more important for any harvest (Rai and Uhl, 2004). The recent studies have suggested that the emphasis on NTFPs as a major income sources for the local communities and unscientific extraction might be a problem for conservation for future population of species (Redford and Padoch, 1992).

The regeneration of the over exploited species in the forest takes a long time and alarming reduction of economically important tree species may cause severe effect on the future generations (Bhattacharya et al., 2002). For example, the extraction of tapsi gum has gone from subsistence-collection to large-scale commercial extraction and unscientific exploitation.

The study area, there are 183 plant species of Magnoliophyta (Angiosperms) which provide minor forest products (MFPs). The NTFPs belong to 149 genera representing 64 families (Dicots / Magnoliopsida-164 and Monocots / Liliopsida -19) (Omkar et al., 2012). The NTFPs are extracted throughout the year in case of gums/resins (Anogeissus latifolia, Gardenia gummifera, Firmiana simplex), fibre (Hardwickia binata), culms (Dendrocalamus strictus) and wood for toys (Givotia moluccana). As per the parts gathered, fruits are used more (nine), followed by seeds (six). Twin uses are found with Aegle marmelos (fruit, wood), Diospyros melanoxylon (leaf, fruit), Madhuca longifolia var. latifolia (flower, fruit), Phyllanthus emblica (fruit, wood), Soymida febrifuga (fruit, wood) and Terminalia bellerica (fruit, wood). NTFPs largely yield food (edible) and medicines. The NTFPs are collected by the rural people is for their self-use ( $8 \%)$, commercial $(56 \%)$ or both (36\%) (Tab. 2).

\section{Conclusion}

The natural vegetation predominates the forests with dry deciduous species like Tectona grandis, Chloroxylon swietenia, Xylia xylocarpa, Terminalia arjuna, Adina cordifolia, Mitragyna parviflora, Anogeissus latifolia, Ziziphus oenopolia, Helicteres isora and Dendrocalamus strictus. The rapid degradation occurred due to over exploitation, biotic pressure (grazing), large scale extension works in the form of mining, irrigation projects/dams, illegal felling, and conversion of forest land to agricultural land use (encroachments). The extraction of NTFPs without proper scientific training might be a problem for the conservation of NTFP species. The harvesting impacts on species survival and forest ecosystem of the particular area are directly related to the demand of the product and dependence of the community. There is an immediate need to take necessary steps to conserve the NTFP plant taxa for the sustainability and empowerment of ethnic and non-ethnic people of Adilabad district. 
Omkar Kanneboyena, Sateesh Suthari, A. Ragan and Vatsavaya S. Raju / Our Nature (2015), 13(1): 1-7.

\section{Acknowledgements}

The authors are thankful to the Telangana State Forest Department, for permission to enter forest and local people, particular to tribal communities who extended their cooperation for collection of primary data. The authors thank the Head, Department of Botany, Kakatiya University, Warangal, for facilities. Dr Sateesh Suthari is a recipient of the Start-Up Research Grant (Young Scientists) SERB/LS-293/2014 and working on 'Plant taxonomic surveillance and survey of contaminated and polluted ecosystems in Peri-Urban Hyderabad: A randomized crossover study of populations and communities' funded by Science and Engineering Research Board (SERB).

\section{References}

Anonymous 1975. Gazetteer of Adilabad District. Government of Andhra Pradesh, Government Press, Hyderabad.

Anonymous 2011. Census Report. Government of Andhra Pradesh, Hyderabad, India.

Anonymous 2013. Andhra Pradesh State of Forest Report. Andhra Pradesh Forest Department, Government of Andhra Pradesh, Hyderabad.

Bhattacharya, P. and S.F. Hayat 2004. Sustainable NTFP management for rural development: a case from Madhya Pradesh, India. Int. Forestry Rev. 6: 161-168. http://dx.doi.org/10.1505/ifor.6.2.161.38 399

Bhattacharya, P., B. Joshi, N.K. Bhagat and S.F. Hayat 2002. Sustainable harvesting of kullu (Sterculia urens) gum. Indian Inst. Forest Manag. Newsletter 1-2: 3-5.

Malhotra, K.C. and P. Bhattacharya 2010. Forest and Livelihood. Publ. CESS, Hyderabad. 246p.

Omkar, K. 2010. Non-Timber Forest Products- their diversity and availability, and the economic subsistence of the rural people in Adilabad district of Andhra Pradesh. Department of Botany, Kakatiya University, Warangal. (Ph.D. Thesis)

Omkar, K., A. Ragan and V.S. Raju 2008. Economic empowerment of tribal women of Adilabad district of Andhra Pradesh, utilizing non-timber forest products. In Proc. Nation. Seminar on "Globalization-Agricultural Development of Tribes, Issues and Challenges" organized by Kakatiya University, Warangal, Andhra Pradesh. pp. 96-98.

Omkar, K., S. Suthari, A. Ragan, A. Samata and V.S. Raju 2012. Diversity of NTFPs and their utilization in Adilabad district of Andhra Pradesh, India, Journal of Plant Studies 1(1): 33-46. http://dx.doi.org/10.5539/jps.v1n1p33

Pimental, D., M. McNair, L. Buck, M. Pimental and J. Kamil 1997. The value of forests to world food security. Human Ecol. 25(1): 91-121. http://dx.doi.org/10.1023/A:1021987920278

Rai, N.D. and C.F. Uhl 2004. Forest product use, conservation and livelihoods: the case of Uppage fruit harvest in the Western Ghats, India. Cons. Soc. 2: 289-313.

Redford, K.H. and C. Padoch 1992. Conservation of Neotopical Forests. Working from Traditional Resource Use. Columbia University Press, New York.

Silori, C.S., M. Mehar, M.A. Khalid and V. Paul 2005. Non-timber Forest Products: conservation status and management priorities the community managed forest of Andhra Pradesh, South India. Int. J. Sustain. Dev. World Ecol. 12: 1-13. http://dx.doi.org/10.1080/13504500509469643

Sinha, A. and K.S. Bawa 2002. Harvesting techniques, hemiparasites and fruit production in two non-timber forest tree species in south India. Forest Ecol. Manag. 168: 289-300. http://dx.doi.org/10.1016/S0378-1127(01)00747-2

Suthari, S. 2013. Biodiversity Characterization and Aboveground Vegetation Carbon Pool Assessment in Northern Telangana at Landscape Level Using Geospatial Technique. Department of Botany, Kakatiya University, Warangal. (Ph.D. Thesis) 